\title{
BIOCHAR: AN EFFICIENT WAY TO MANAGE LOW WATER AVAILABILITY IN PLANTS
}

\author{
TAYYAB, M..$^{1,2^{*}}$ - ISLAM, W..$^{3,4,5}$ - KHALIL, F. ${ }^{1,2}$-ZIQIN, P. ${ }^{1,2}$ - CAIFANG, Z. ${ }^{1,2}$ - ARAFAT, Y. ${ }^{6}-$ \\ HUI, L. ${ }^{1,2}$ - RIZWAN, M $^{7}$. - AHMAD, K. ${ }^{1,2}$ - WAHEED, S. ${ }^{8}$ - TARIN, M. W. K. ${ }^{9}-$ HUA, Z. ${ }^{1,2^{*}}$ \\ ${ }^{I}$ Key Laboratory of Sugarcane Biology and Genetic Breeding, Ministry of Agriculture, Fujian \\ Agriculture and Forestry University, Fuzhou 350002, China \\ ${ }^{2}$ College of Crop Science, Fujian Agriculture and Forestry University, Fuzhou, 350002, China \\ ${ }^{3}$ College of Plant Protection, Fujian Agriculture and Forestry University \\ Fuzhou 350002, China \\ ${ }^{4}$ State Key Laboratory of Ecological Pest Control for Fujian and Taiwan Crops \\ Fuzhou 350002, China \\ ${ }^{5}$ Govt. of Punjab, Agriculture Department, Lahore, Pakistan \\ ${ }^{6}$ College of Life Sciences, Fujian Agriculture and Forestry University Fuzhou \\ Fuzhou 350002, China \\ ${ }^{7}$ College of Honey Bee Sciences, Fujian Agriculture and Forestry University Fuzhou \\ Fuzhou 350002, China \\ ${ }^{8}$ College of Horticulture, Fujian Agriculture and Forestry University Fuzhou \\ Fuzhou 350002, China \\ ${ }^{9}$ College of Forestry, Fujian Agriculture and Forestry University Fuzhou \\ Fuzhou 350002, China \\ *Corresponding authors \\ zhanghua4553@sina.com (Z.Hua); $1151901001 @ f a f u . e d u . c n$ (M. Tayyab) \\ (Received 28 $8^{\text {th }}$ Jan 2018; accepted $16^{\text {th }}$ Apr 2018)
}

\begin{abstract}
Global food security is continuously being haunted by the rapid increase in population and drastic climate changes. Drought stress (DS) negatively affects the soil fertility and plant growth. Drought often induces cell dehydration and ultimately inhibits cell expansion and division, leaf size, stem elongation, root proliferation, disturbed stomatal oscillations, plant water and nutrient uptake. Biochar (BC), being a carbon-rich material, ameliorates the adverse effects of drought on plants. BC is a carbonrich $(65-90 \%)$ solid product of biomass pyrolysis that contains numerous pores and oxygen functional groups and aromatic surfaces. BC application modifies microbial habitats by improving the soil's physical properties. Additionally, BC porosity can decrease soil bulk density and improve soil aeration conditions. $\mathrm{BC}$ can increase the available water contents that influence nutrient accessibility to microbial cells. BC application increases the plant growth, biomass and yield of crops under water deficit conditions. It also enhances nutrient uptake, photosynthesis and modifies gas exchange characteristics in plants growing under water paucity. Additionally, it improves the physical, biological properties and water holding capacity of the soil. Keeping in view the tremendous importance of BC, this review highlights its potential in mitigating the DS in plants and sums up by revealing future prospects regarding its role in improvement of soils. Overall, this review can contribute towards the better understanding of the BC-mediated tolerance mechanisms in plants under low water availability.

Keywords: drought, soil, reclamation, remediation, pyrolysis
\end{abstract}




\section{Introduction}

The current world population is approximately 7.3 billion and is predicted to reach 8.5 billion by 2030 (Warner and Jones, 2017). As we know that global food security is continuously being haunted by the rapid increase in population, shrinking resources and drastic climatic changes therefore, to feed the large population, improved cropping systems and strategies are dire need of time (Khalil et al., 2016; Lesk et al., 2016; Rauf et al., 2016). In many regions of the world, biotic and abiotic stresses such as drought, high salinity and extreme temperatures results in the most injurious limitations for the plant's growth and productivity (Khan et al., 2017; Noman et al., 2017; Thalmann and Santelia, 2017; Islam et al., 2018a,b). Among the abiotic stresses, DS is reckoned as the most injurious environmental factor causing significant losses of growth as well as yield of the plants (Ali et al., 2016; Calvo-Polanco et al., 2016; Dubois et al., 2017). The drought has severely affected terrestrial agriculture in the past and recent times. DS along with other abiotic stresses like heavy metal contamination not only limits plant production but also pose more risks to human health (Arshad et al., 2016; Noman and Aqeel, 2017). For example, Liu et al. (2017d) revealed that DS differentially influenced the translocation and redistribution of Cadmium in peanut plants during various developmental stages. It often induces cell dehydration and ultimately result in inhibition of cell expansion and division, leaf size, stem elongation, root proliferation, disturbed stomatal oscillations, plant water and nutrient uptake as well as enhance proline accumulation (Kaushal and Wani, 2016; Khalil et al., 2016; Noman et al., 2015). Moreover, it also curtails photosynthesis (Khalil et al., 2016; Khan et al., 2017). Additionally, it causes oxidative stress through the production of reactive oxygen species (ROS) (Apel and Hirt, 2004; Cruz de Carvalho, 2008). It lowers soil water potential and water use efficiency (WUE) (Kaushal and Wani, 2016). Consequently, combating DS is a challenging task for achieving food security under the drastic climatic changes worldwide.

Historically, several techniques were utilized to improve the soil structural and biochemical properties. For example, thousands year ago, Romans and Greeks incorporated the animal manure and human feces in the soil as an organic amendment to increase the soil quality and fertility. At that time they knew that previously legumes grown field can be beneficial for wheat crop cultivation. Earlier different materials (e.g., plant residues, farm manure sea-shells, and other waste) were adopted as an organic amendment to improve the crop growth. Currently, BC, compost and animal manure as a soil amendment is well-known while crop straw, sewage sludge, peat, wood shavings, and sawdust are also used for soil amendment to improve quality and fertility. BC amendments have large-scale agricultural, economic and environmental benefits (Kumar et al., 2017). BC is a highly porous, fine-grained charcoal that can hold carbon combusted under low oxygen at relatively high temperatures (Fazal and Bano, 2016). Like bioethnol, it can be produced from different organic materials such as plant residues (Llorach-Massana et al., 2017; Tayyab et al., 2018), pecan shells, sawdust (Komnitsas et al., 2016), peanut hulls (Chu et al., 2017), Hardwood (Laird et al., 2017), paper mill sludge (Cho et al., 2017), Palm kernel shell and Palm oil sludge (Lee et al., 2017), pine and jarrah woods (Jiang et al., 2017), rice straw (Liu et al., 2017a), cotton stem, wheat straw, rice husk, corn stem, peach branch, walnut shell, yak manure, eucalyptus wood sawdust (Wang and Liu, 2017), hemlock char and switchblade grass char (Yu et al., 2017) poultry manure (Barati et al., 2018) and pig manure (Liu et al., 2017a). Different types of biomass and the thermochemical conditions are used to 
pyrolyze it significantly to influence the quality of $\mathrm{BC}$ and its potential uses (Chen et al., 2011; Yu et al., 2017a). The production of BC is quite similar to charcoal, the production of which is one of the oldest developed technologies (Lehmann and Joseph, 2009). However, it is entirely different from charcoal as it is not primarily used as a fuel, but for atmospheric carbon (C) capture and storage, or bio-sequestration. The porous structure of char particles enhances the water-retaining capacity and nutrient retention of soil, as well microbial accumulation. Due to its perceived benefits of increasing nutrient and water retention, it is used as a soil conditioner that is very promising and useful for soil amendments (Skjemstad et al., 2002; Yu et al., 2017a Sarfraz et al., 2017). Additionally, BC modifies microbial habitats by improving the soil's physical properties. Its porosity can decrease soil bulk density and improve soil aeration conditions. It can also increase the available water contents that influence nutrient accessibility to microbial cells. In addition, it can increase water contents at the permanent wilting point, which indicates the capability of BC, via its high porosity, to store water that is unavailable to plants. Keeping water in this manner is beneficial, especially in sandy and degraded soils (Abel et al., 2013; Skjemstad et al., 2002). Moreover, the improved water retention capacity means that there is a more excellent capability of the soil to hold water against dry-wet cycles in the natural environment, which can favor the maintenance of a stable microbial activity (Liang et al., 2014). A significant body of knowledge reported that BC amendment enhances plant growth, seed production, biomass and nutrient absorption under the drought conditions (Bamminger et al., 2016; Gonzaga et al., 2017; Paneque et al., 2016). However, according to our literature survey, a comprehensive review of the beneficial and effective role of $\mathrm{BC}$ upon plants under water deficit conditions is not documented yet. Hence, we reviewed the $\mathrm{BC}$ application in agricultural production under DS to give attention to the development of soil health and fertility to feed the increasing population.

\section{Adverse effect of drought stress on soil properties}

Drought is one of the most severe abiotic stresses. It strongly affects soil microbial activity, fungal properties, soil respiration and litter decomposition (Geng et al., 2015; Hoogmoed et al., 2016; Mariotte et al., 2015; Schmidt et al., 2017). The significance of the microbial community in soil ecosystem functioning is well known which plays a pivotal role in soil fertility and improvement in soil structure (Wall and Bardgett, 2012; Arafat et al., 2017). For example, microbial communities produce enzymes and are responsible for $90 \%$ of soil organic matter (SOM) decomposition (C mineralization), which determines nutrient turnover (Bastida et al., 2013; Swift et al., 1979). Nevertheless, drought can affect soil microbial communities by restricting diffusion of substrate, inhibitory compounds (e.g., plant and antimicrobial secondary metabolites), enzymes and inducing microbial physiological stress (Davidson and Janssens, 2006). As compared to fungal communities, bacterial communities are sensitive to disturbances caused by drought and their response directly affects soil fertility and soil structure (Bardgett and Wardle, 2010). 


\section{Adverse effect of drought stress on plant yield and biomass}

Drought negatively influences the plant growth and crop production. It affects the plant development causing severe reductions in crop productivity. Additionally, it can initiate a series of physiological and biochemical changes in plants. It also decreases dry matter production, leaf area index, number of seeds per plant, seed size and finally the grain yield. Moreover, reduction in intercellular carbon dioxide concentration, stomatal conductance and transpiration is also associated with it. Chlorophyll fluorescence is negatively correlated with DS as it has severe effects on leaf gaseous exchange rate and chlorophyll fluorescence depending on various developmental stages of the plant and the duration of DS. Under drought, some processes such as plant hydraulic status, phytohormones, osmotic adjustment, and ROS signaling control the reduction of plant growth.

\section{Production and physicochemical characteristics of biochar amendments}

$\mathrm{BC}$ is a recalcitrant source of soil organic carbon combusted under low oxygen at relatively high temperatures (Fazal and Bano, 2016). Theoretically, almost any form of organic material can be utilized for its production (Kuppusamy et al., 2016). However, its properties can vary widely depending on feedstock and processing conditions (Brewer et al., 2017). For attaining several benefits of sustainable agriculture, the amendment of $\mathrm{BC}$ is being increasingly discussed as a drought mitigation tool. In the last decade, tremendous increase in the number of publications using a variety of BCs addressed as drought mitigation approach shows the high interest of researcher regarding the enhancing scope of BC. Tripathi et al. (2016a) presented the concept of sustainable BC production. Standard techniques used for BC production are rotating kilns, vertical silo-type reactors, hydrothermal carbonization, gasification, and slow and fast pyrolysis. BCs are categorized with a high concentration of total organic carbon (30-70\%) depending upon the pyrolysis conditions (aeration, temperature and time), mineral contents $(\mathrm{Na}, \mathrm{Mg}, \mathrm{K}, \mathrm{Fe}$, etc.) $\mathrm{EC}, \mathrm{pH}$, volatile matter and ash concentration (Jindo et al., 2014; Qayyum et al., 2015; Yu et al., 2017). However, the BC properties are significantly affected by the feedstock nature (Brewer et al., 2017). It is produced from the thermal conservation of biomass feedstock's (Fig. 1). Among various techniques (e.g., pyrolysis, gasification, and hydrothermal carbonization), pyrolysis which heats the biomass at relatively low temperatures $\left(300-900^{\circ} \mathrm{C}\right)$ in the absence of oxygen, is the most cost-effective and efficient method for BC production (Cha et al., 2016; Qian et al., 2015). Additionally, pyrolysis can be subdivided into slow and fast pyrolysis, according to the different heating rates. Even though, there exist some disadvantages such as energy inefficiency and demand for long production duration, slow pyrolysis is still widely used for BC production presently due to the comparatively higher BC yield (Liu et al., 2015; Tripathi et al., 2016a). The characterization of sophisticated methods contains the quantification and identification of surface functional groups, polycyclinc aromatic hydrocarbon, aromatic compounds, active surface area and scanning electron microscopy (Hale et al., 2012; Harris et al., 2013). $\mathrm{BC}$ has demonstrated its multifunctional roles in carbon sequestration (Crombie et al., 2013). The linkage of BC properties and its application are shown in Figure 2. Consequently, before their implementation, BC must be carefully analyzed (Aller et al., 2017; Kuppusamy et al., 2016). BC amendments may have large-scale environmental, economic as well as agricultural benefits. Deep investigation of the BC-mediated plant 
resistance mechanisms against abiotic and biotic stresses will enhance our further understanding of the better agronomic management of economically important crops (Kumar et al., 2017).

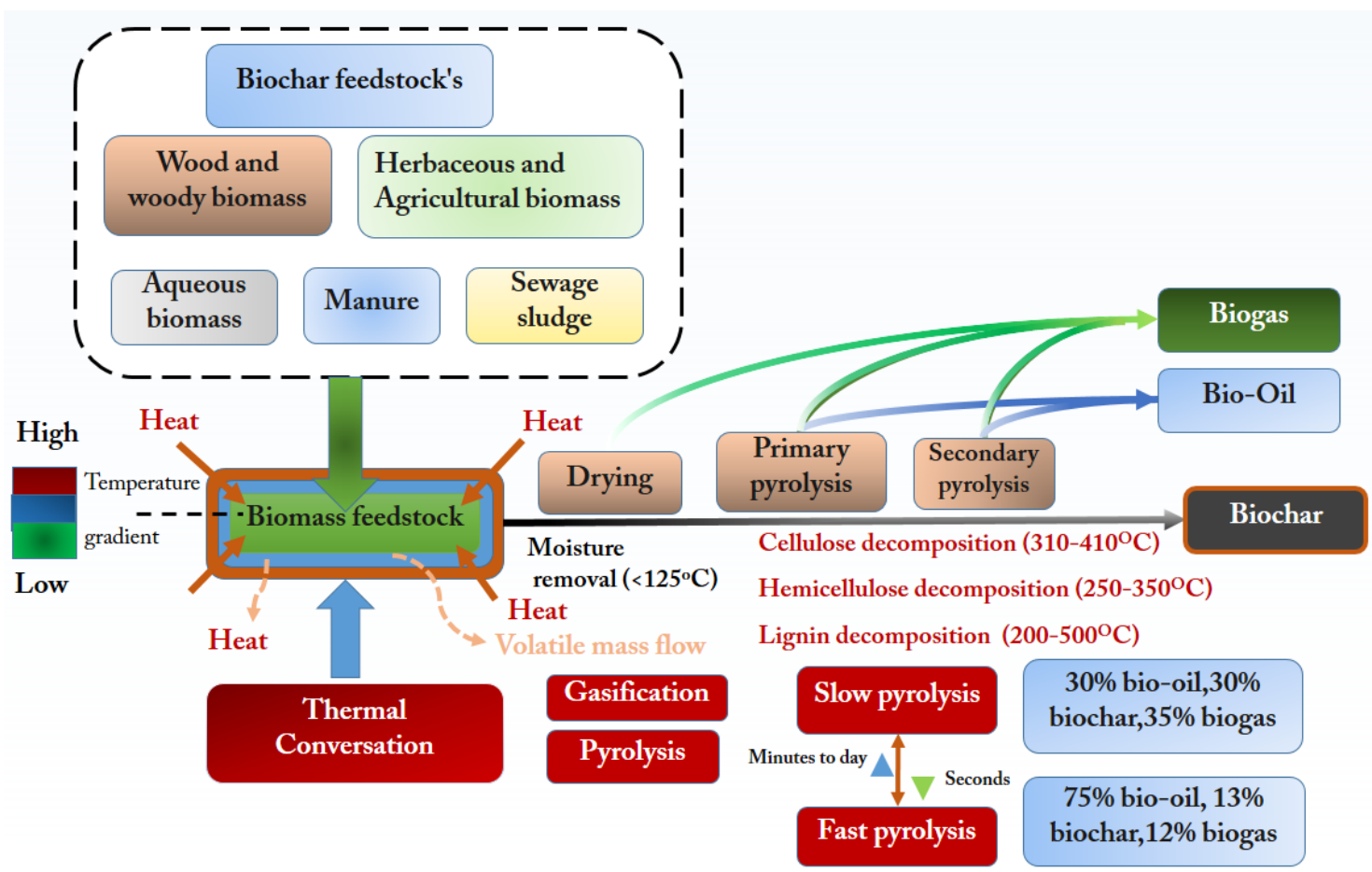

Figure 1. The brief introduction of biochar feedstock and its production processes (slightly modified from Xiao et al., 2016)

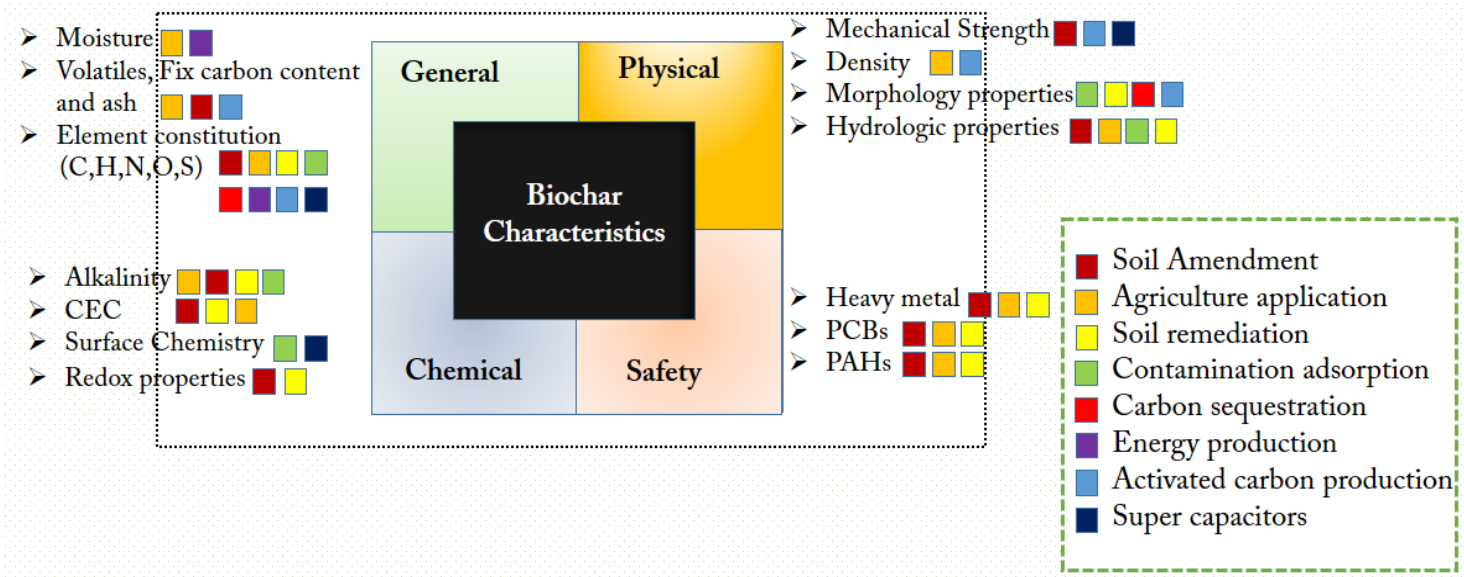

Figure 2. A brief introduction of the linkage between biochar properties and its application (modified from Xiao et al., 2016). Here, the more number of square boxes designate the improvement in various soil properties via utilization of biochar through various applications which are represented by different color. Moreover, the abbreviations included are C (carbon), $H$ (hydrogen), $N$ (Nitrogen), O (Oxygen), S (Sulpher), CEC (Cation exchange capacity), PCB (Polychlorinated biphenyl) and PAH (Polycyclic aromatic hydrocarbons) 


\section{Biochar improves plant development and biomass under drought stress}

The beneficial effects of BC application under limited water conditions have been widely reported (Akhtar et al., 2015; Paneque et al., 2016; Ramzani et al., 2017; Rogovska et al., 2014). The BC amendment improved growth and biomass of plants under drought-stress (Table 1; Fig. 3). Similarly, use of BC exhibited the highest vegetative growth and seed production of field-grown sunflower under non-irrigation conditions (Paneque et al., 2016). Its application enhanced tomato fruit quality, growth and yield under deficit irrigation (Agbna et al., 2017). Similarly, its use supports the growth of winter rapeseed under drought conditions (Bamminger et al., 2016). Likewise, Basso et al. (2013) found a significant increase in soil WHC in a soil column study with hardwood $\mathrm{BC}$ and predicted that the increased WHC might enhance available water capacity (AWC $=$ available water between field capacity and permanent wilting point) for crops. Tomato seedlings were protected from wilting due to improved soil moisture content with higher $(30 \% \mathrm{v} / \mathrm{v})$ rates of $\mathrm{BC}$ amendments in sandy soils (Mulcahy et al., 2013).

\section{Biochar amendment effects upon soil under drought stress}

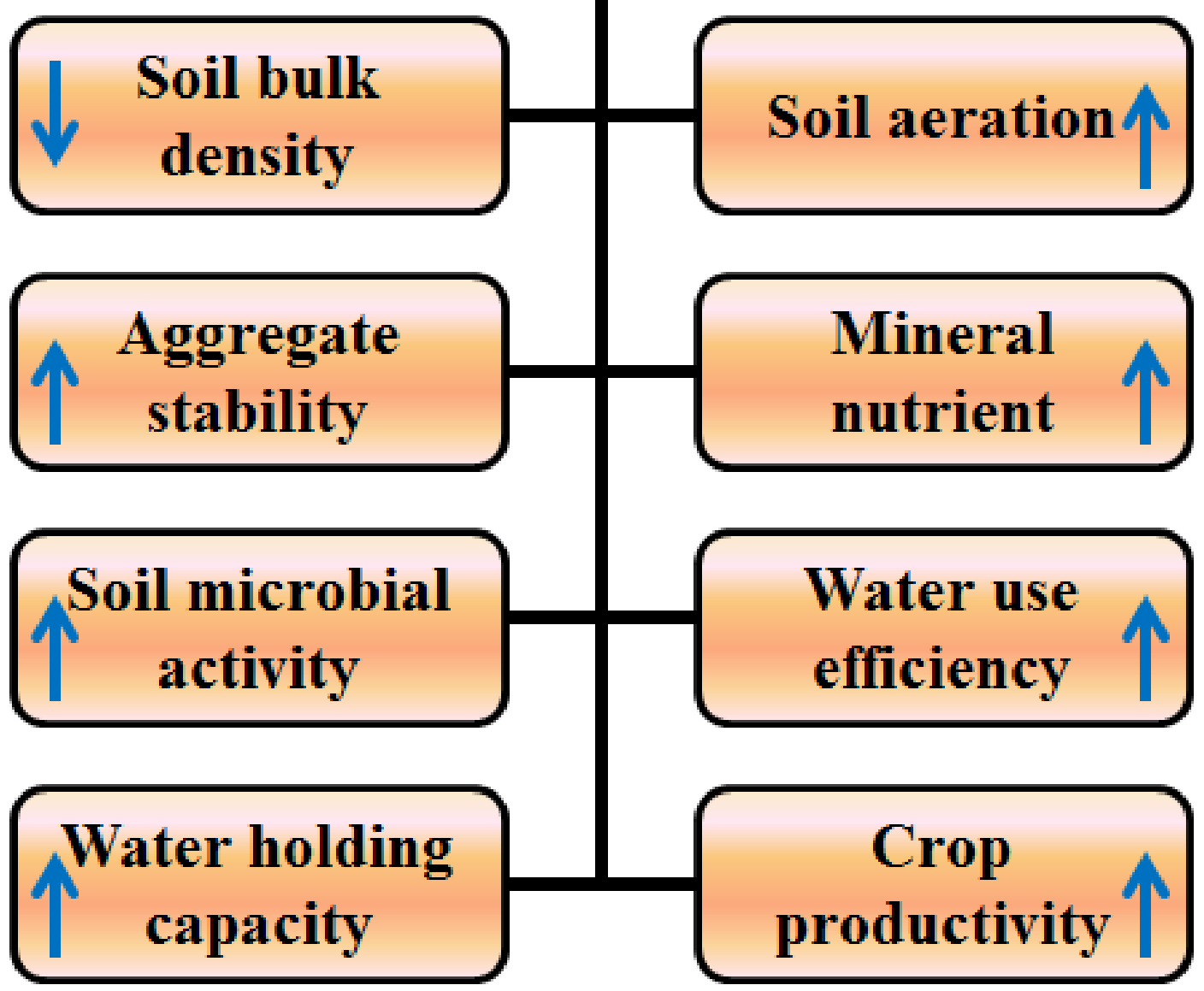

Figure 3. Biochar possible effects under drought stress at both plant and soil level 
Table 1. Impact of biochar on plant growth and soil properties evident by recent research findings

\begin{tabular}{|c|c|c|c|c|c|c|}
\hline $\begin{array}{l}\text { Feedstock and } \\
\text { pyrolysis } \\
\text { conditions }\end{array}$ & $\begin{array}{c}\text { Rate of } \\
\text { application }\end{array}$ & Soil type & $\begin{array}{c}\text { Experiment } \\
\text { condition }\end{array}$ & $\begin{array}{l}\text { Plant } \\
\text { species }\end{array}$ & Effects & References \\
\hline $\begin{array}{c}\text { Corn Cob } \\
\text { Biochar, } 4500^{\circ} \mathrm{C}\end{array}$ & $20 \mathrm{tha}^{-1}$ & $\begin{array}{l}\text { Sandy } \\
\text { loam }\end{array}$ & Field & soybean & $\begin{array}{c}\text { Enhanced seedling } \\
\text { growth }\end{array}$ & Hafeez et al., 2017 \\
\hline $\begin{array}{c}\text { Wheat straw and } \\
\text { sugarcane }\end{array}$ & 5 and $10 \mathrm{tha}^{-1}$ & $\begin{array}{c}\text { Sandy } \\
\text { clay loam }\end{array}$ & Field & - & $\begin{array}{l}\text { Increased microbial } \\
\text { biomass carbon, } \\
\text { phosphatase activity, } \\
\text { urease activity and } \\
\text { dehydrogenase activity }\end{array}$ & $\begin{array}{l}\text { Mehmood et al., } \\
2017\end{array}$ \\
\hline $\begin{array}{l}\text { Rice husk }+ \\
\text { shell of cotton } \\
\text { seed, } 400{ }^{\circ} \mathrm{C}\end{array}$ & 0 and $5 \%$ & $\begin{array}{l}\text { Sandy } \\
\text { loam }\end{array}$ & Pot & Tomato & $\begin{array}{c}\text { Increased fruit yield, Gs, } \\
\text { Pn, RWC and WUE of } \\
\text { leaves }\end{array}$ & Akhtar et al., 2014 \\
\hline $\begin{array}{l}\text { Akiko pear } \\
\text { trees, } 500{ }^{\circ} \mathrm{C}\end{array}$ & $9 \mathrm{t} \mathrm{hm}^{-2}$ & - & Field & \begin{tabular}{|c|} 
Pyrus \\
ussuriensis \\
Maxim \\
\end{tabular} & $\begin{array}{c}\text { Improve the defense of } \\
\text { plant leaves against } \\
\text { drought stress }\end{array}$ & Lyu et al., 2016 \\
\hline $\begin{array}{c}\text { Wheat straw } \\
\text { biochar, } 500{ }^{\circ} \mathrm{C}\end{array}$ & $\begin{array}{c}0,1,2 \text {, and } \\
3 \%\end{array}$ & $\begin{array}{l}\text { Sandy } \\
\text { subsoil }\end{array}$ & Pot & Maize & $\begin{array}{c}\text { Maintained leaf water } \\
\text { potential, stomatal } \\
\text { conductance, } \\
\text { photosynthesis }\end{array}$ & Ahmed et al., 2016 \\
\hline Grapevine wood & $15 \mathrm{t} \mathrm{ha}^{-1}$ & $\begin{array}{l}\text { Sandy } \\
\text { loam }\end{array}$ & Field & $\begin{array}{c}\text { Helianthus } \\
\text { annuus L. }\end{array}$ & $\begin{array}{l}\text { Improved the plant } \\
\text { development and } \\
\text { productivity; increased } \\
\text { the WHC of the soil }\end{array}$ & $\begin{array}{l}\text { Paneque et al., } \\
2016\end{array}$ \\
\hline $\begin{array}{c}\text { Biomass of } \\
\text { Lantana camara, } \\
450{ }^{\circ} \mathrm{C} \\
\end{array}$ & 0,1 , and $3 \%$ & $\begin{array}{l}\text { Sandy } \\
\text { loam }\end{array}$ & Pot & Okra & $\begin{array}{l}\text { Increased leaf area, plant } \\
\text { height, photosynthesis, } \\
\text { Gs, and WUE }\end{array}$ & Batool et al., 2015 \\
\hline $\begin{array}{l}\text { Wood-chip } \\
\text { sievings at } \\
550-600^{\circ} \mathrm{C} \\
\end{array}$ & $0,1.5$, and $3 \%$ & Sandy & Pot & Maize & $\begin{array}{c}\text { Increased stem and dry } \\
\text { leaf mass, RWC, and } \\
\text { photosynthesis }\end{array}$ & Haider et al., 2015 \\
\hline $\begin{array}{c}\text { Hardwood } \\
\text { (maple), } 350{ }^{\circ} \mathrm{C}\end{array}$ & $\begin{array}{c}0 \%, 1 \% \text {, and } \\
2 \%\end{array}$ & $\begin{array}{l}\text { sandy } \\
\text { loam }\end{array}$ & Pot & $\begin{array}{l}\text { Milk thistle } \\
\text { (Silybum } \\
\text { marianum } \\
\text { L. Gaertn) } \\
\end{array}$ & $\begin{array}{l}\text { Improved soil moisture } \\
\text { holding capacity }\end{array}$ & $\begin{array}{l}\text { Keshavarz Afshar } \\
\text { et al., } 2016\end{array}$ \\
\hline $\begin{array}{l}\text { Poultry litter, } \\
\quad 400{ }^{\circ} \mathrm{C}\end{array}$ & $3 \%$ & $\begin{array}{l}\text { sandy- } \\
\text { clay-loam } \\
\text { Soil }\end{array}$ & Pot & - & $\begin{array}{l}\text { Increased the resistance } \\
\text { of both the bacterial and } \\
\text { fungal networks to } \\
\text { drought }\end{array}$ & Liang et al., 2014 \\
\hline
\end{tabular}

Improving plant WUE has the potential to decrease plant susceptibility to limited water conditions. Amending BC with soil has been proposed as a way to ameliorate the WUE as it has been revealed to improve the WHC of soils (Licht and Smith, 2017). It enhanced hydrology characteristics, soil physical properties, increased soil water content and grain yields and WUE under natural conditions (Xiao et al., 2016). Different BCs have different impacts on soil water relations. For example, amendment of fresh $\mathrm{BC}$ with sandy loam soil enhanced the plant available water (PAW) but not aged BC. Addition of fresh and aged BC amendment with silt loam soil did not affect PAW and WUE. It indicates that BC type and $\mathrm{BC}$ age have variable impacts on PAW and WUE, meaning that $\mathrm{BC}$ amendments can increase plant growth and soil water relations under water-limited conditions for some but not all soils (Aller et al., 2017). Similarly, in another study, Licht and Smith (2017) demonstrated amendment of lignocellulosic BC to forest soils reduced DS in pine-oak systems. Akhtar et al. (2014) 
described that under limited freshwater resources, application of partial rootzone drying irrigation (PRD) in combination with BC might be a promising approach for saving water and enhancing productivity and quality of tomato. Similarly, Agbna et al. (2017) revealed that integration of $\mathrm{BC}$ amendment (BA) with deficit irrigation (DI) represents a viable technique that can save water without reducing tomato yields as well as improving the quality of the fruits. This method can mainly be used in areas that regularly struggle with water shortage. More precise optimal levels would likely need to be determined for commercial purposes in future studies as they are likely to be case specific, depending on soil texture, BC type and climate among other factors (Karer et al., 2013). Vaccari et al. (2015) suggests that BC amendment may ensure the same yield while using less external input such as irrigation water. A $10 \%$ yield increase of barley (Hordeum vulgare) with $\mathrm{BC}$ amendment in a chernozem region under prolonged DS was attributed to increased water availability. Githinji (2014) reported that the leaf quality rate of tomato increased with BC application in sandy loam soil as compared to the unamended control. Barley is grown in the coarse sandy subsoil underwater, use of $1 \%$ straw gasification BC increased the root and growth shoot. However, gasification $\mathrm{BC}$ was not active on barley growth under water stress in sandy loam soils (Hansen et al., 2016). Studies have described that the application of BC improved the photosynthesis of plants under DS (Haider et al., 2015; Lyu et al., 2016; Xiao et al., 2016).

BC significantly improved the relative water contents (RWC), stomatal conductance (Gs), chlorophyll contents, WUE, photosynthetic rate (Pn) and stomatal density of drought-stressed tomato leaves (Akhtar et al., 2014). Its application increased the leaf relative water contents (RWC), transpiration rate and osmotic potential of droughtstressed maize as compared to the control (Haider et al., 2015). Kammann and Graber (2015) study the influence of BC on drought tolerance of Chenopodium quinoa displayed increased drought tolerance, growth and water-use efficiency of quinoa. BC amendment in soil improves the soil water content, photosynthesis, leaf water potential and transpiration under scarce water conditions. However, application of BC resulted in increased soil water content in Danish coarse sandy soil under drought. Leaf water potential, photosynthesis, and transpiration of Maize plants were maintained by 2 and 3\% BC addition to the subsoil (Ahmed et al., 2016). Similarly, Haider et al. (2015) reported that $\mathrm{BC}$ use in poor sandy soils could improve plant growth by enhancing soilplant-water relations and photosynthesis under both deficit and excess water. Lyu et al. (2016) revealed the addition of BC could strengthen the defense of plant leaves against DS by influencing electron transfer and regulating the activity of protective enzymes, thereby reducing the effects of drought damage to the photosynthetic apparatus. This showed that $\mathrm{BC}$ response under DS might vary with soil, BC type and plant species.

\section{Biochar inoculate with microorganisms mitigate drought stress}

Studies have shown that BC may minimize water stress in plants when applied with microorganisms (Liu et al., 2017b; Nadeem et al., 2017). Egamberdieva et al. (2017) reported inoculation of BC with Bradyrhizobium sp. Enhance the growth, biomass, phosphorus $(\mathrm{P})$ uptake and nitrogen $(\mathrm{N})$, and nodulation in lupin (Lupinus angustifolius L.) seedlings under DS as compared to the only microbial inoculation. Nadeem et al. (2017) reported inoculation of BC with Pseudomonas fluorescens, reduced the harmful impact of DS on cucumber (Cucumis sativus L.) growth, increased the shoot length, 
shoot biomass, root length and root biomass as compared to inoculated control. Besides, significant improvements in chlorophyll and relative water contents, as well as a reduction in leaf electrolyte leakage, demonstrated the effectiveness of this approach. In another study, Liu et al. (2017b) reported that inoculation of BC (birch wood, $500{ }^{\circ} \mathrm{C}$ ) with Rhizophagus irregularis decreased the WUE, N, leaf area, $\mathrm{P}$ in potato and did not adversely impacted the root biomass and soil $\mathrm{pH}$ under limited root zone water as compared to control. However, under limited irrigation soil amendment with woodderived BC (30 mg.ha ${ }^{-1}$ ) had no significant effect on soil biota groups such as protozoa, bacteria, fungi, nematodes and arthropods (Pressler et al., 2017).

The application of $\mathrm{BC}$ with Arbuscular mycorrhizal fungi can enhance drought tolerance of the host plant by physiological mechanisms in nutrient adsorption and biochemical mechanisms, e.g. hormones, osmotic adjustment and antioxidant systems. However, application of BC to the agricultural soil with Arbuscular mycorrhizal fungi stimulated the growth of extra-radical hyphae in soil and increased mycorrhizal colonization of roots. As the water potential of the soil was the same with and without $\mathrm{BC}$ amendment, it is unlikely that the observed effects on plant growth were related to possible benefits from the water holding capacity of the BC (Mickan et al., 2016).

Previous studies have revealed that the utilization of $\mathrm{BC}$ by microbial inoculation can be helpful in alleviating DS in plants, depending on the type of $\mathrm{BC}$ or other factors. Additionally, $\mathrm{BC}$ is increasingly discussed as a climate change (drought) mitigation tool, but there is limited knowledge about its interactive effects with future soil DS, possibly influencing its stability as well as its beneficial effects on soil microorganisms and plants.

\section{Biochar improves soil biological and physiochemical properties}

Several studies have shown that BC improves the physical properties of soil under DS conditions (Bamminger et al., 2016; Hansen et al., 2016; Zhang et al., 2017). Ye et al. (2015) has shown BC had features that could improve soil properties such as density, acidity, moisture retention, and the stability of heavy metal ions in the soil. Zhang et al. (2017) has shown that soil physicochemical properties improved by the BC and increased abundance and diversity of bacteria have contributed to the ability of $\mathrm{BC}$ to protect plants against tobacco bacterial wilt. Total porosity (TP) increased and soil bulk density (BD) decreased, air properties improved (FAC and FAP) and there was an increase in the retention of water available for plants (Pranagal et al., 2017). Liang et al. (2014) also reported that BC application in calcareous soils decreased the significantly bulk density of soil while soil WHC increased. Abel et al. (2013) showed that BC application in sandy soil increased the total pore space, decreased the soil Bulk density (BD) and water retention at permanent wilting point. The equilibration of corn residue $\mathrm{BC}$ in a sandy loam soil for 30 days decreased the BD and increased water holding capacity WHC of the soil (Igalavithana et al., 2017). The BC amendment decreases the $\mathrm{BD}$ as well as an increase in the soil water contents, have observed in a variety of soils with different soil texture (Herath et al., 2013; Igalavithana et al., 2017). Burrell et al. (2016) showed that straw BC was the most effective at improving plant available water and soil aggregate stability in a coarse-textured soil. Similarly, Baiamonte et al. (2015) reported that application of $\mathrm{BC}$ had increased the aggregate stability in sandy-clay soil. However, under crop cultivation, more detailed studies are required to appraise the impact of $\mathrm{BC}$ on soil aggregate stability. In general, BC amendment improves the soil 
physical properties under reduced water supply and beneficial for plant growth under semiarid conditions. Though, under drought, additional investigations are required about the $\mathrm{BC}$ amendment. In addition, BC aging affected the soil properties, and more studies are needed to evaluate the BC aging effect on soil properties under DS (Arthur et al., 2015). In addition, soil water retention may vary with $\mathrm{BC}$ sources and pyrolysis condition. For example, Similarly, Narzari et al. (2017) demonstrated that the BC produced at higher temperature had higher $\mathrm{pH}$ and WHC. However, it is suitable for soil having water retention capacity as an amendment. Further investigations, by using different BCs at different rate of application and various pyrolysis conditions might be useful to improve the effectiveness of BC on the soil WHC under DS (Lee et al., 2015). The addition of $\mathrm{BC}$ increases the WHC of the soil, which is a critical factor in enhancing plant growth and yield under drought (Akhtar et al., 2015; Basso et al., 2013; Foster et al., 2016; Lehmann et al., 2011). An increase in the WHC of soil under DS might be because of higher CEC and porous structure of BC (Laghari et al., 2016). Studies testified that application of BC improved the soil CEC as compared (Lychuk et al., 2015). Artiola et al. (2012) reported that the application of pine forest waste BC in the soil retained water in the soil, however under laboratory conditions; significant portion of $\mathrm{BC}$ pores remained empty. However, there might be the difference in the WHC of BC under field conditions, which need to be investigated in the near future. The application of $\mathrm{BC}$ at vineyard improved the soil water content measured on different time (Baronti et al., 2014). BC amendment to sandy soils increased WHC and to retain vast amounts of PAW for crops for more extended periods of times (Basso et al., 2013). Liu et al. (2017c) revealed BC with a high intraporosity and irregular shapes will most efficiently increase water storage in coarse soils. Feedstock, pyrolysis temperature and charring residence time are various factors involved might be useful to produce $\mathrm{BC}$ with varying porosity.

Ajayi and Horn (2016) compared the potential of clay and BC in improving mechanical resilience and water retention of sandy soil. Soil water retention capacity increased with Na-bentonite at more negative matric potentials, whereas BC was efficient to increasing soil water retention capacity at saturation which might be caused by the increase in soil porosity. The BC application in the sandy loam soil improved the WHC of the soil used for rice cultivation (De Melo Carvalho et al., 2014). The field application of $\mathrm{BC}$ in vertisol increased the wheat growth and developed the ability of soil to retain water under semiarid Mediterranean conditions (Olmo et al., 2014). Githinji (2014) reported that application of BC in the field increased the macroporosity of loamy sand soil.

These studies revealed that BC might be efficient to increase the WHC of soils. Most of the studies were conducted in sandy soils. However, more studies are needed to explore the functions of $\mathrm{BC}$ in increasing the WHC of soil with different texture and environmental conditions. Limited research investigated characteristics of $\mathrm{BC}$ produced from various feedstocks to determine which are the most effective for improved soil water holding capacity WHC of soil.

\section{How biochar can be applied to improve crop yield}

When applying BC to soil for improving its fertility, the BC should be located near the soil's surface in the root zone, where the bulk of nutrient cycling and uptake by plants takes place. Certain systems may benefit from the application of $\mathrm{BC}$ in layers 
below the root zone, for example during landscaping for carbon (C) sequestration or moisture management. Similarly, if BC is to be applied to soil solely for C sequestration purposes, placement should be done deeper in the soil. When deciding how to apply BC to soil, the specific cropping system must be taken into consideration. The likelihood of wind and water erosion losses of $\mathrm{BC}$ is reduced when it is thoroughly incorporated into soil, however, plowing and soil mixing are not possible or desirable in all cropping systems, at all times. In conventional field cropping systems, BC should ideally be managed using traditional farm machinery and incorporated into routine field operations. This will ensure that the costs of using BC are kept as low as possible. For example, $\mathrm{BC}$ can be applied and incorporated together with lime, since lime is often applied as a fine solid which must be well incorporated into soil. The majority of BC field trials reported to date used this method for incorporating BC into soil (Haque et al., 2014; Julie Major et al., 2010; Yamato et al., 2006). Broadcasting can be done by hand on small scales or on larger scales by using lime/solid manure spreaders or broadcast seeders. Moistened BC materials may be better suited to application with manure spreaders than lime spreaders. Incorporation can be achieved using any plowing method at any scale, including hand hoes, animal draft plows, disc harrows, chisels, rotary hoes, etc. As mentioned above, wind losses from applying and incorporating fine BC materials can be significant and precautions must be taken to minimize this. Banding of seeds and fertilizers is a routine operation in mechanized agriculture and involves applying an amendment in a narrow band, usually using equipment that cuts the soil open, without disturbing the entire soil surface. Banding allows BC to be placed inside the soil while minimizing soil disturbance, making it possible to apply $\mathrm{BC}$ after crop establishment. However, the amounts of BC that can be applied in this way are lower than those which can be achieved by broadcast applications. Wheat yields in Western Australia were improved by banding BC (Blackwell et al., 2007). When working by hand, BC can be applied in furrows opened using a hoe and closed after applying BC. Mixing it with other soil amendments such as manure, compost or lime before soil application can improve efficiency by reducing the number of field operations required. Since $\mathrm{BC}$ has been shown to sorb nutrients and protects them against leaching (Major et al., 2009), mixing with BC may improve the efficiency of manure or other amendment application. BC can also be mixed with liquid manures and applied as a slurry. Fine BCs will likely be best suited to this type of application using existing application equipment, and dust problems associated with these would be addressed. It could also be mixed with manure in holding ponds and could potentially reduce gaseous nitrogen losses as it does when applied to soil (Spokas et al., 2009; Yanai et al., 2007). Where high-resolution data on soil characteristics and farm machinery equipped with geographical positioning systems are available, it would possible to apply BC preferentially to areas of fields where fertility is low. Further studies are needed to address how long BC intraporosity, particle size, and particle shape will last after field application.

\section{Conclusion and future perspectives}

DS severely decreases crop yield and growth. Studies reported above showed that BC application increased the plant growth and biomass under DS. BC application in soil increases the nutrient uptake, photosynthesis and modified gas exchange features in plants. More studies are required to evaluate the role of BC under DS conditions. The 
studies mentioned above showed that $\mathrm{BC}$ application with microbes might improve the plant tolerance against DS. However, time-course and detailed studies are needed to explore the long-term effectiveness of $\mathrm{BC}+$ microbes on the growth of plants and to separate the effects of $\mathrm{BC}$ on different stages of microbial life cycles under prevailing conditions of limited water. Amendment of $\mathrm{BC}$ with the inoculation of Arbuscular mycorrhizal fungi can enhance drought tolerance mycorrhizal plants through physiological mechanisms in nutrient uptake and biochemical mechanisms regarding adjustment, osmotic, hormones and antioxidant systems. Extensive studies are needed for the development of models for the better recommendation of $\mathrm{BC}$ rate based on soil, plant, and environmental conditions.

\section{REFERENCES}

[1] Abel, S., Peters, A., Trinks, S., Schonsky, H., Facklam, M., Wessolek, G. (2013): Impact of biochar and hydrochar addition on water retention and water repellency of sandy soil. Geoderma 202: 03-10.

[2] Agbna, G. H. D., Dongli, S., Zhipeng, L., Elshaikh, N. A., Guangcheng, S., Timm, L. C. (2017): Effects of deficit irrigation and biochar addition on the growth, yield, and quality of tomato. - Scientia Horticulturae 222: 03-10.

[3] Ahmed, F., Arthur, E., Plauborg, F., Andersen, M. N. (2016): Biochar Effects on Maize Physiology and Water Capacity of Sandy Subsoil. - Mechanization in Agriculture and Conserving of the Resources 6: 03-10.

[4] Ajayi, A. E., Horn, R. (2016): Comparing the potentials of clay and biochar in improving water retention and mechanical resilience of sandy soil. - International Agrophysics 30(4): 03-10.

[5] Akhtar, S. S., Li, G., Andersen, M. N., Liu, F. (2014): Biochar enhances yield and quality of tomato under reduced irrigation. - Agricultural Water Management 138: 03-10.

[6] Akhtar, S. S., Andersen, M. N., Liu, F. (2015): Residual effects of biochar on improving growth, physiology and yield of wheat under salt stress. - Agricultural Water Management 158: 03-10.

[7] Ali, Q., Haider, M. Z., Iftikhar, W., Jamil, S., Javed, M. T., Noman, A., .. Perveen, R. (2016): Drought tolerance potential of Vigna mungo L. lines as deciphered by modulated growth, antioxidant defense, and nutrient acquisition patterns. - Brazilian Journal of Botany 39(3): 03-10.

[8] Aller, D., Rathke, S., Laird, D., Cruse, R., Hatfield, J. (2017): Impacts of fresh and aged biochars on plant available water and water use efficiency. - Geoderma 307: 03-10.

[9] Apel, K., Hirt, H. (2004): REACTIVE OXYGEN SPECIES: Metabolism, Oxidative Stress, and Signal Transduction. - Annual Review of Plant Biology 55(1): 03-10.

[10] Arafat, Y., Wei, X., Jiang, Y., Chen, T., Saqib, H. S. A., Lin, S., Lin, W. (2017): Spatial distribution patterns of root-associated bacterial communities mediated by root exudates in different aged ratooning tea monoculture systems. International Journal of Molecular Sciences 18(8): 1727.

[11] Arshad, M., Ali, S., Noman, A., Ali, Q., Rizwan, M., Farid, M., Irshad, M. K. (2016): Phosphorus amendment decreased cadmium $(\mathrm{Cd})$ uptake and ameliorates chlorophyll contents, gas exchange attributes, antioxidants, and mineral nutrients in wheat (Triticum aestivum L.) under Cd stress. - Archives of Agronomy and Soil Science 62(4): 03-10.

[12] Arthur, E., Tuller, M., Moldrup, P., de Jonge, L. W. (2015): Effects of biochar and manure amendments on water vapor sorption in a sandy loam soil. - Geoderma 243-244: 03-10.

[13] Artiola, J. F., Rasmussen, C., Freitas, R. (2012): Effects of a Biochar-Amended Alkaline Soil on the Growth of Romaine Lettuce and Bermudagrass. - Soil Science 177(9): 03-10. 
[14] Baiamonte, G., De Pasquale, C., Marsala, V., Cimò, G., Alonzo, G., Crescimanno, G., Conte, P. (2015): Structure alteration of a sandy-clay soil by biochar amendments. Journal of Soils and Sediments 15(4): 03-10.

[15] Bamminger, C., Poll, C., Sixt, C., Högy, P., Wüst, D., Kandeler, E., Marhan, S. (2016): Short-term response of soil microorganisms to biochar addition in a temperate agroecosystem under soil warming. - Agriculture, Ecosystems and Environment 233: 0310.

[16] Barati, M., Bakhtiari, F., Mowla, D., Safarzadeh, S. (2018): Comparison of the effects of poultry manure and its biochar on barley growth in petroleum contaminated soils. International Journal of Phytoremediation 20(2): 98-103.

[17] Bardgett, R. D., Wardle, D. A. (2010): Aboveground-Belowground Linkages: Biotic Interactions, Ecosystem Processes, and Global Change. - Oxford Series in Ecology and Evolution. Oxford Universtiy Press, New York.

[18] Baronti, S., Vaccari, F. P., Miglietta, F., Calzolari, C., Lugato, E., Orlandini, S., ... Genesio, L. (2014): Impact of biochar application on plant water relations in Vitis vinifera (L.). - European Journal of Agronomy 53: 03-10.

[19] Basso, A. S., Miguez, F. E., Laird, D. A., Horton, R., Westgate, M. (2013): Assessing potential of biochar for increasing water-holding capacity of sandy soils. - Gcb Bioenergy 5(2): 03-10.

[20] Bastida, F., Torres, I. F., Hernández, T., Bombach, P., Richnow, H. H., García, C. (2013): Can the labile carbon contribute to carbon immobilization in semiarid soils? Priming effects and microbial community dynamics. - Soil Biology and Biochemistry 57: 03-10.

[21] Batool, A., Taj, S., Rashid, A., Khalid, A., Qadeer, S., Saleem, A. R., Ghufran, M. A. (2015): Potential of soil amendments (Biochar and Gypsum) in increasing water use efficiency of Abelmoschus esculentus L. Moench. - Frontiers in Plant Science 6: 03-10.

[22] Blackwell, P., Shea, S., Storer, P., Solaiman, Z., Kerkmans, M., Stanley, I. (2007): Improving wheat production with deep banded Oil Mallee Charcoal in Western Australia. - Paper presented at the International Agrichar Initiative, 30 April-2 May, Terrigal, Australia.

[23] Brewer, C. E., Hall, E. T., Schmidt-Rohr, K., Laird, D. A., Brown, R. C., Zygourakis, K. (2017): Temperature and reaction atmosphere effects on the properties of corn stover biochar. - Environmental Progress and Sustainable Energy 36(3): 03-10.

[24] Burrell, L. D., Zehetner, F., Rampazzo, N., Wimmer, B., Soja, G. (2016): Long-term effects of biochar on soil physical properties. - Geoderma 282: 03-10.

[25] Calvo-Polanco, M., Sánchez-Romera, B., Aroca, R., Asins, M. J., Declerck, S., Dodd, I. C., ... Ruiz-Lozano, J. M. (2016): Exploring the use of recombinant inbred lines in combination with beneficial microbial inoculants (AM fungus and PGPR) to improve drought stress tolerance in tomato. - Environmental and Experimental Botany 131: 0310 .

[26] Cha, J. S., Park, S. H., Jung, S. C., Ryu, C., Jeon, J. K., Shin, M. C., Park, Y. K. (2016): Production and utilization of biochar: A review. - Journal of Industrial and Engineering Chemistry 40: 1-15.

[27] Chen, X., Chen, G., Chen, L., Chen, Y., Lehmann, J., McBride, M. B., Hay, A. G. (2011): Adsorption of copper and zinc by biochars produced from pyrolysis of hardwood and corn straw in aqueous solution. - Bioresource Technology 102(19): 03-10.

[28] Cho, D.-W., Kwon, G., Yoon, K., Tsang, Y. F., Ok, Y. S., Kwon, E. E., Song, H. (2017): Simultaneous production of syngas and magnetic biochar via pyrolysis of paper mill sludge using CO 2 as reaction medium. - Energy Conversion and Management 145: 0310.

[29] Chu, G., Zhao, J., Chen, F., Dong, X., Zhou, D., Liang, N., ... Steinberg, C. E. W. (2017): Physi-chemical and sorption properties of biochars prepared from peanut shell using thermal pyrolysis and microwave irradiation. - Environmental Pollution 227: 0310. 
[30] Crombie, K., Mašek, O., Sohi, S. P., Brownsort, P., Cross, A. (2013): The effect of pyrolysis conditions on biochar stability as determined by three methods. - GCB Bioenergy 5(2): 03-10.

[31] Cruz de Carvalho, M. H. (2008): Drought stress and reactive oxygen species: Production, scavenging and signaling. - Plant Signaling and Behavior 3(3): 03-10.

[32] Davidson, E. A., Janssens, I. A. (2006): Temperature sensitivity of soil carbon decomposition and feedbacks to climate change. - Nature 440(7081): 03-10.

[33] De Melo Carvalho, M. T., De Holanda Nunes Maia, A., Madari, B. E., Bastiaans, L., Van Oort, P. A. J., Heinemann, A. B., ... Meinke, H. (2014): Biochar increases plant-available water in a sandy loam soil under an aerobic rice crop system. - Solid Earth 5(2): 03-10.

[34] Dubois, M., Claeys, H., Van den Broeck, L., Inzé, D. (2017): Time of day determines Arabidopsis transcriptome and growth dynamics under mild drought. - Plant, Cell and Environment 40(2): 03-10.

[35] Egamberdieva, D., Reckling, M., Wirth, S. (2017): Biochar-based Bradyrhizobium inoculum improves growth of lupin (Lupinus angustifolius L.) under drought stress. European Journal of Soil Biology 78: 03-10.

[36] Fazal, A., Bano, A. (2016): Role of plant growth-promoting rhizobacteria (pgpr), biochar, and chemical fertilizer under salinity stress. - Communications in Soil Science and Plant Analysis 47(17): 03-10.

[37] Foster, E. J., Hansen, N., Wallenstein, M., Cotrufo, M. F. (2016): Biochar and manure amendments impact soil nutrients and microbial enzymatic activities in a semi-arid irrigated maize cropping system. - Agriculture, Ecosystems and Environment 233: 03-10.

[38] Geng, S. M., Yan, D. H., Zhang, T. X., Weng, B. S., Zhang, Z. B., Qin, T. L. (2015): Effects of drought stress on agriculture soil. - Natural Hazards 75(2): 03-10.

[39] Githinji, L. (2014): Effect of biochar application rate on soil physical and hydraulic properties of a sandy loam. - Archives of Agronomy and Soil Science 60(4): 03-10.

[40] Gonzaga, M. I. S., Mackowiak, C. L., Comerford, N. B., da Veiga Moline, E. F., Shirley, J. P., Guimaraes, D. V. (2017): Pyrolysis methods impact biosolids-derived biochar composition, maize growth and nutrition. - Soil and Tillage Research 165: 03-10.

[41] Hafeez, Y., Iqbal, S., Jabeen, K., Shahzad, S., Jahan, S., Rasul, F. (2017): Effect of biochar application on seed germination and seedling growth of Glycine Max (L.) Merr. under drought stress. - Pakistan Journal of Botany 49: 03-10.

[42] Haider, G., Koyro, H.-W. W., Azam, F., Steffens, D., Müller, C., Kammann, C. (2015): Biochar but not humic acid product amendment affected maize yields via improving plant-soil moisture relations. - Plant and Soil 395(1-2): 03-10.

[43] Hale, S. E., Lehmann, J., Rutherford, D., Zimmerman, A. R., Bachmann, R. T., Shitumbanuma, V., ... Cornelissen, G. (2012): Quantifying the total and bioavailable polycyclic aromatic hydrocarbons and dioxins in biochars. - Environmental Science and Technology 46(5): 03-10.

[44] Hansen, V., Hauggaard-Nielsen, H., Petersen, C. T., Mikkelsen, T. N., Müller-Stöver, D. (2016): Effects of gasification biochar on plant-available water capacity and plant growth in two contrasting soil types. - Soil and Tillage Research 161: 03-10.

[45] Haque, A., Tang, C. K., Islam, S., Ranjith, P. G., Bui, H. H. (2014): Biochar sequestration in lime-slag treated synthetic soils: a green approach to ground improvement. - Journal of Materials in Civil Engineering 26(12): 03-10.

[46] Harris, K., Gaskin, J., Cabrera, M., Miller, W., Das, K. C. (2013): Characterization and mineralization rates of low temperature peanut hull and pine chip biochars. - Agronomy 3(2): 03-10.

[47] Herath, H. M. S. K., Camps-Arbestain, M., Hedley, M. (2013): Effect of biochar on soil physical properties in two contrasting soils: An Alfisol and an Andisol. - Geoderma 209210: 03-10. 
[48] Hoogmoed, M., Cunningham, S. C., Baker, P. J., Beringer, J., Cavagnaro, T. R. (2016): Effects of wetting frequency and afforestation on carbon, nitrogen and the microbial community in soil. - Agriculture, Ecosystems and Environment 231: 03-10.

[49] Igalavithana, A. D., Ok, Y. S., Niazi, N. K., Rizwan, M., Al-Wabel, M. I., Usman, A. R. A., ... Lee, S. S. (2017): Effect of corn residue biochar on the hydraulic properties of sandy loam soil. - Sustainability (Switzerland) 9(2): 03-10.

[50] Islam, W., Adnan, M., Tayyab, M., Hussain, M., Islam, S. U. (2018a): Phyto-metabolites; an impregnable shield against plant viruses. - Natural Product Communications 13(1): 03-10.

[51] Islam, W., Qasim, M., Noman, A., Adnan, M., Tayyab, M., Farooq, H., ... Wang, L. (2018b): Plant microRNAs: Front line players against invading pathogens. - Microbial Pathogenesis 118: 9-17. https://doi.org/10.1016/j.micpath.2018.03.008.

[52] Jiang, S., Nguyen, T. A. H., Rudolph, V., Yang, H., Zhang, D., Ok, Y. S., Huang, L. (2017): Characterization of hard-and softwood biochars pyrolyzed at high temperature. Environmental Geochemistry and Health 39(2): 03-10.

[53] Jindo, K., Mizumoto, H., Sawada, Y., Sonoki, T. (2014): Physical and chemical characterization of biochars derived from different agricultural residues. Biogeosciences 11(23): 03-10.

[54] Kammann, C., Graber, E. R. (2015): Biochar Effects on Plant Ecophysiology. - In: Lehmann, J., Joseph, S. (eds.) Biochar for Environmental Management: Science, Technology and Implementation. Routledge, Abingdon.

[55] Karer, J., Wimmer, B., Zehetner, F., Kloss, S., Soja, G. (2013): Biochar application to temperate soils: effects on nutrient uptake and crop yield under field conditions. Agricultural and Food Science 22(4): 03-10.

[56] Kaushal, M., Wani, S. P. (2016): Rhizobacterial-plant interactions: strategies ensuring plant growth promotion under drought and salinity stress. - Agriculture, Ecosystems and Environment 231: 03-10.

[57] Keshavarz Afshar, R., Hashemi, M., DaCosta, M., Spargo, J., Sadeghpour, A. (2016): Biochar application and drought stress effects on physiological characteristics of Silybum marianum. - Communications in Soil Science and Plant Analysis 47(6): 03-10.

[58] Khalil, F., Rauf, S., Monneveux, P., Anwar, S., Iqbal, Z. (2016): Genetic analysis of proline concentration under osmotic stress in sunflower (Helianthus annuus L.). Breeding Science 66(4): 03-10.

[59] Khan, A., Anwar, Y., Hasan, M. M., Iqbal, A., Ali, M., Alharby, H. F., ... Hasanuzzaman, M. (2017): Attenuation of drought stress in Brassica seedlings with exogenous application of $\mathrm{Ca} 2+$ and $\mathrm{H} 2 \mathrm{O} 2$. - Plants 6(2): 03-10.

[60] Komnitsas, K., Zaharaki, D., Bartzas, G., Kaliakatsou, G., Kritikaki, A. (2016): Efficiency of pecan shells and sawdust biochar on $\mathrm{Pb}$ and $\mathrm{Cu}$ adsorption. - Desalination and Water Treatment 57(7): 03-10.

[61] Kumar, A., Elad, Y., Tsechansky, L., Abrol, V., Lew, B., Offenbach, R., Graber, E. R. (2017): Biochar potential in intensive cultivation of Capsicum anuum L. (sweet pepper): Crop yield and plant protection. - Journal of the Science of Food and Agriculture 98(2): 495-503.

[62] Kuppusamy, S., Thavamani, P., Megharaj, M., Venkateswarlu, K., Naidu, R. (2016): Agronomic and remedial benefits and risks of applying biochar to soil: current knowledge and future research directions. - Environment International 87: 03-10.

[63] Laghari, M., Hu, Z., Mirjat, M. S., Xiao, B., Tagar, A. A., Hu, M. (2016): Fast pyrolysis biochar from sawdust improves the quality of desert soils and enhances plant growth. Journal of the Science of Food and Agriculture 96(1): 03-10.

[64] Laird, D. A., Novak, J. M., Collins, H. P., Ippolito, J. A., Karlen, D. L., Lentz, R. D., ... Van Pelt, R. S. (2017): Multi-year and multi-location soil quality and crop biomass yield responses to hardwood fast pyrolysis biochar. - Geoderma 289: 03-10. 
[65] Lee, S. S., Shah, H. S., Awad, Y. M., Kumar, S., Ok, Y. S. (2015): Synergy effects of biochar and polyacrylamide on plants growth and soil erosion control. - Environmental Earth Sciences 74(3): 03-10.

[66] Lee, X. J., Lee, L. Y., Gan, S., Thangalazhy-Gopakumar, S., Ng, H. K. (2017): Biochar potential evaluation of palm oil wastes through slow pyrolysis: Thermochemical characterization and pyrolytic kinetic studies. - Bioresource Technology 236: 03-10.

[67] Lehmann, J., Joseph, S. (2009): Biochar for Environmental Management: An Introduction. - In: Lehmann, J., Joseph, S. (eds.) Biochar for Environmental Management - Science and Technology (Vol. 1). Earthscan, London.

[68] Lehmann, J., Rillig, M. C., Thies, J., Masiello, C. A., Hockaday, W. C., Crowley, D. (2011): Biochar effects on soil biota-a review. - Soil Biology and Biochemistry 43(9): 03-10.

[69] Lesk, C., Rowhani, P., Ramankutty, N. (2016): Influence of extreme weather disasters on global crop production. - Nature 529(7584): 03-10.

[70] Liang, C., Zhu, X., Fu, S., Méndez, A., Gascó, G., Paz-Ferreiro, J. (2014): Biochar alters the resistance and resilience to drought in a tropical soil. - Environmental Research Letters 9(6): 03-10.

[71] Liang, F., Li, G., Lin, Q., Zhao, X. (2014): Crop Yield and Soil Properties in the First 3 Years After Biochar Application to a Calcareous Soil. - Journal of Integrative Agriculture 13(3): 03-10.

[72] Licht, J., Smith, N. (2017): The influence of lignocellulose and hemicellulose biochar on photosynthesis and water use efficiency in seedlings from a Northeastern US pine-oak ecosystem. - Journal of Sustainable Forestry 37(1): 25-37.

[73] Liu, W. J., Jiang, H., Yu, H. Q. (2015): Development of biochar-based functional materials: toward a sustainable platform carbon material. - Chemical Reviews 115(22): 12251-12285.

[74] Liu, Y., Yao, S., Wang, Y., Lu, H., Brar, S. K., Yang, S. (2017a): Bio-and hydrochars from rice straw and pig manure: Inter-comparison. - Bioresource Technology 235: 03-10.

[75] Liu, C., Liu, F., Ravnskov, S., Rubæk, G. H., Sun, Z., Andersen, M. N. (2017b): Impact of wood biochar and its interactions with mycorrhizal fungi, phosphorus fertilization and irrigation strategies on potato growth. - Journal of Agronomy and Crop Science 203(2): 03-10.

[76] Liu, Z., Dugan, B., Masiello, C. A., Gonnermann, H. M. (2017c): Biochar particle size, shape, and porosity act together to influence soil water properties. - PLoS ONE 12(6): 03-10.

[77] Liu, C., Yu, R., Shi, G. (2017d): Effects of drought on the accumulation and redistribution of cadmium in peanuts at different developmental stages. - Archives of Agronomy and Soil Science 63(8): 03-10.

[78] Llorach-Massana, P., Lopez-Capel, E., Peña, J., Rieradevall, J., Montero, J. I., Puy, N. (2017): Technical feasibility and carbon footprint of biochar co-production with tomato plant residue. - Waste Management 67: 03-10.

[79] Lychuk, T. E., Izaurralde, R. C., Hill, R. L., McGill, W. B., Williams, J. R. (2015): Biochar as a global change adaptation: predicting biochar impacts on crop productivity and soil quality for a tropical soil with the Environmental Policy Integrated Climate (EPIC) model. - Mitigation and Adaptation Strategies for Global Change 20(8): 03-10.

[80] Lyu, S., Du, G., Liu, Z., Zhao, L., Lyu, D. (2016): Effects of biochar on photosystem function and activities of protective enzymes in Pyrus ussuriensis Maxim. under drought stress. - Acta Physiologiae Plantarum 38(9): 03-10.

[81] Major, J., Steiner, C., Downie, A., Lehmann, J. (2009): Biochar Effects on Nutrient Leaching. In: Lehmann, J., Joseph, S. (eds.) Biochar for Environmental Management Science and Technology. Earthscan, London. 
[82] Major, J., Rondon, M., Molina, D., Riha, S. J., Lehmann, J. (2010): Maize yield and nutrition during 4 years after biochar application to a Colombian savanna oxisol. - Plant and Soil 333(1): 03-10.

[83] Mariotte, P., Robroek, B. J. M., Jassey, V. E. J., Buttler, A. (2015): Subordinate plants mitigate drought effects on soil ecosystem processes by stimulating fungi. - Functional Ecology 29(12): 03-10.

[84] Mehmood, S., Akmal, M., Imtiaz, M., Bashir, S., Rizwan, M., Shakeel, Q., ... Ali, S. (2017): Differential effect of wheat straw and sugarcane derived biochars on microbial and enzymatic activities of rain-fed soil. - J. Environ. Agric. Sci 10: 03-10.

[85] Mickan, B. S., Abbott, L. K., Stefanova, K., Solaiman, Z. M. (2016): Interactions between biochar and mycorrhizal fungi in a water-stressed agricultural soil. - Mycorrhiza 26(6): 03-10.

[86] Mulcahy, D. N., Mulcahy, D. L., Dietz, D. (2013): Biochar soil amendment increases tomato seedling resistance to drought in sandy soils. - Journal of Arid Environments 88: 03-10.

[87] Nadeem, S. M., Imran, M., Naveed, M., Khan, M. Y., Ahmad, M., Zahir, Z. A., Crowley, D. E. (2017): Synergistic use of biochar, compost and plant growth promoting rhizobacteria for enhancing cucumber growth under water deficit conditions. - Journal of the Science of Food and Agriculture.

[88] Narzari, R., Bordoloi, N., Sarma, B., Gogoi, L., Gogoi, N., Borkotoki, B., Kataki, R. (2017): Fabrication of biochars obtained from valorization of biowaste and evaluation of its physicochemical properties. - Bioresource Technology 242: 03-10.

[89] Noman, A., Aqeel, M. (2017): miRNA-based heavy metal homeostasis and plant growth. - Environmental Science and Pollution Research 24(11): 03-10.

[90] Noman, A., Ali, S., Naheed, F., Ali, Q., Farid, M., Rizwan, M., Irshad, M. K. (2015): Foliar application of ascorbate enhances the physiological and biochemical attributes of maize (Zea mays L.) cultivars under drought stress. - Archives of Agronomy and Soil Science 61(12): 03-10.

[91] Noman, A., Fahad, S., Aqeel, M., Ali, U., Amanullah, Anwar, S., ... Zainab, M. (2017): miRNAs: Major modulators for crop growth and development under abiotic stresses. Biotechnology Letters 39(5): 685-700.

[92] Olmo, M., Alburquerque, J. A., Barrón, V., del Campillo, M. C., Gallardo, A., Fuentes, M., Villar, R. (2014): Wheat growth and yield responses to biochar addition under Mediterranean climate conditions. - Biology and Fertility of Soils 50(8): 03-10.

[93] Paneque, M., José, M., Franco-Navarro, J. D., Colmenero-Flores, J. M., Knicker, H. (2016): Effect of biochar amendment on morphology, productivity and water relations of sunflower plants under non-irrigation conditions. - Catena 147: 03-10.

[94] Pranagal, J., Oleszczuk, P., Tomaszewska-Krojańska, D., Kraska, P., Różyło, K. (2017): Effect of biochar application on the physical properties of Haplic Podzol. - Soil and Tillage Research 174: 03-10.

[95] Pressler, Y., Foster, E. J., Moore, J. C., Cotrufo, M. F. (2017): Coupled biochar amendment and limited irrigation strategies do not affect a degraded soil food web in a maize agroecosystem, compared to the native grassland. - GCB Bioenergy 9(8): 13441355.

[96] Qayyum, M. F., Abid, M., Danish, S., Saeed, M. K., Ali, M. A. (2015): Effects of various biochars on seed germination and carbon mineralization in an alkaline soil. - Pakistan J Agric Sci 51: 03-10.

[97] Qian, K., Kumar, A., Zhang, H., Bellmer, D., Huhnke, R. (2015): Recent advances in utilization of biochar. - Renewable and Sustainable Energy Reviews 42: 1055-1064.

[98] Ramzani, P. M. A., Shan, L., Anjum, S., Ronggui, H., Iqbal, M., Virk, Z. A., Kausar, S. (2017): Improved quinoa growth, physiological response, and seed nutritional quality in three soils having different stresses by the application of acidified biochar and compost. Plant Physiology and Biochemistry 116: 03-10. 
[99] Rauf, S., Al-Khayri, J. M., Zaharieva, M., Monneveux, P., Khalil, F. (2016): Breeding strategies to enhance drought tolerance in crops. - Advances in Plant Breeding Strategies: Agronomic, Abiotic and Biotic Stress Traits 2: 03-10.

[100] Rogovska, N., Laird, D. A., Rathke, S. J., Karlen, D. L. (2014): Biochar impact on Midwestern Mollisols and maize nutrient availability. - Geoderma 230: 03-10.

[101] Sarfraz, R., Shakoor, A., Abdullah, M., Arooj, A., Hussain, A., Xing, S. (2017): Impact of integrated application of biochar and nitrogen fertilizers on maize growth and nitrogen recovery in alkaline calcareous soil. -Soil Science and Plant Nutrition 63(5): 488-498

[102] Schmidt, P.-A., Schmitt, I., Otte, J., Bandow, C., Römbke, J., Bálint, M., Rolshausen, G. (2017): Season-long experimental drought alters fungal community composition but not diversity in a grassland soil. - Microbial Ecology 75(2): 468-478.

[103] Skjemstad, J. O., Reicosky, D. C., Wilts, A. R., McGowan, J. A. (2002): Charcoal carbon in US agricultural soils. - Soil Science Society of America Journal 66(4): 03-10.

[104] Spokas, K. A., Koskinen, W. C., Baker, J. M., Reicosky, D. C. (2009): Impacts of woodchip biochar additions on greenhouse gas production and sorption/degradation of two herbicides in a Minnesota soil. - Chemosphere 77(4): 03-10.

[105] Swift, M. J., Heal, O. W., Anderson, J. M. (1979): Decomposition in Terrestrial Ecosystems (Vol. 5). - Univ. of California Press, Berkeley.

[106] Tayyab, M., Noman, A., Waheed, S., Arafat, Y., Ali, F., Zaynab, M., Lin, S., Zhang, H., Lin, W. (2018): Bioethanol production from lignocellulosic biomass by environmentfriendly pretreatment methods: a review. - Applied Ecology and Environmental Research 16(1): 03-10.

[107] Thalmann, M., Santelia, D. (2017): Starch as a determinant of plant fitness under abiotic stress. - New Phytologist 214(3): 03-10.

[108] Tripathi, M., Sahu, J. N., Ganesan, P. (2016): Effect of process parameters on production of biochar from biomass waste through pyrolysis: A review. - Renewable and Sustainable Energy Reviews 55: 03-10.

[109] Vaccari, F. P., Maienza, A., Miglietta, F., Baronti, S., Di Lonardo, S., Giagnoni, L., ... Ranieri, R. (2015): Biochar stimulates plant growth but not fruit yield of processing tomato in a fertile soil. - Agriculture, Ecosystems and Environment 207: 03-10.

[110] Wall, D. H., Bardgett, R. D. (2012): Soil Ecology and Ecosystem Services. - Oxford University Press, Oxford.

[111] Wang, Y., Liu, R. (2017): Comparison of characteristics of twenty-one types of biochar and their ability to remove multi-heavy metals and methylene blue in solution. - Fuel Processing Technology 160: 03-10.

[112] Warner, K. J., Jones, G. A. (2017): A population-induced renewable energy timeline in nine world regions. - Energy Policy 101: 03-10.

[113] Xiao, Q., Zhu, L., Shen, Y., Li, S. (2016): Sensitivity of soil water retention and availability to biochar addition in rainfed semi-arid farmland during a three-year field experiment. - Field Crops Research 196: 03-10.

[114] Yamato, M., Okimori, Y., Wibowo, I. F., Anshori, S., Ogawa, M. (2006): Effects of the application of charred bark of Acacia mangium on the yield of maize, cowpea and peanut, and soil chemical properties in South Sumatra, Indonesia. - Soil Science and Plant Nutrition 52(4): 03-10.

[115] Yanai, Y., Toyota, K., Okazaki, M. (2007): Effects of charcoal addition on N2O emissions from soil resulting from rewetting air-dried soil in short-term laboratory experiments. - Soil Science and Plant Nutrition 53(2): 03-10.

[116] Ye, L., Zhang, J., Zhao, J., Luo, Z., Tu, S., Yin, Y. (2015): Properties of biochar obtained from pyrolysis of bamboo shoot shell. - Journal of Analytical and Applied Pyrolysis 114: 03-10.

[117] Yu, K. L., Lau, B. F., Show, P. L., Ong, H. C., Ling, T. C., Chen, W.-H., ... Chang, J.-S. (2017): Recent developments on algal biochar production and characterization. Bioresource Technology 246: 2-11. 
[118] Yu, O., Harper, M., Hoepfl, M., Domermuth, D. (2017): Characterization of biochar and its effects on the water holding capacity of loamy sand soil: Comparison of hemlock biochar and switchblade grass biochar characteristics. - Environmental Progress and Sustainable Energy 36(5): 1474-1479.

[119] Zang, U., Goisser, M., Häberle, K., Matyssek, R., Matzner, E., Borken, W. (2014): Effects of drought stress on photosynthesis, rhizosphere respiration, and fine-root characteristics of beech saplings: A rhizotron field study. - Journal of Plant Nutrition and Soil Science 177(2): 03-10.

[120] Zhang, C., Lin, Y., Tian, X., Xu, Q., Chen, Z., Lin, W. (2017): Tobacco bacterial wilt suppression with biochar soil addition associates to improved soil physiochemical properties and increased rhizosphere bacteria abundance. - Applied Soil Ecology 112: 03-10. 